DOI: $10.2478 / \mathrm{v} 10025-010-0030-9$

\title{
The dynamics of climate elements and land drainage impact on hydrologic conditions in a lakeland blind drainage area
}

\author{
Bernard OKOŃSKI I), Antoni T. MILER ${ }^{l)}$, Monika PANFIL ${ }^{2)}$ \\ 1) University of Life Sciences in Poznań, Department of Forest Engineering, ul. Mazowiecka 41, \\ 60-623 Poznań, Poland, e-mail: okonski@au.poznan.pl \\ 2) University of Warmia and Mazury in Olsztyn, pl. Łódzki 1, 10-957 Olsztyn-Kortowo, Poland, \\ e-mail: monika.panfil@uwm.edu.pl
}

\begin{abstract}
The assessment of climate dynamics and the impact of land drainage systems on lakeland blind drainage area was the problem studied in the paper. The research area was located based on relative stability of non-climatic physiographic characteristics and water management practices over a longer time-scale. Thus, the influence of non-climatic factors on water storage could be omitted. The study site was situated in Warmia region in the Dopływ spod Nowej Wsi catchment $\left(27.53 \mathrm{~km}^{2}\right)$. One of local seepage ponds called Bagna Ramuckie within the aforementioned catchment was investigated. The study covered the time period since the first half of the $19^{\text {th }}$ century to the year 2005 .

The decisive factors affecting processes of increase and decrease of pond water surface area in considered spatial units were the trends of air temperature over the long time scale. It was indicated that natural enlargement of water surface area in the pond occurred after 40-years long period of air temperature decrease and the decline followed 20-year-long period of air temperature rise. Precipitation did not show any trends for long periods but typical cyclic changes of precipitation over a short time-scale. These pluvial cycles stimulated or destimulated processes of water surface changes additionally over short periods. The first episode of water surface decrease in the seepage pond occurred when air temperature rise trend coincided with intensive land drainage and changes in some land management patterns (the $2^{\text {nd }}$ half of the $19^{\text {th }}$ century). Nevertheless, during the $20^{\text {th }}$ century water management practices were rather stable and did not have any impact on rise or decline of seepage pond water surface area.
\end{abstract}

Key words: dynamics of climate elements, land drainage, seepage pond, surface water decline, wetland

\section{INTRODUCTION}

Climate is the main factor affecting water balance and hydrologic processes in large spatial units. Variable thermal and precipitation conditions in transitory climate of Poland determine the variability of recharge, surface outflow and forms of 
water storage. The effect of non-stationary climate on hydrologic conditions could be associated with long-term variability of thermal and precipitation conditions or with the frequency and intensity of some extreme phenomena like climatic droughts or snow cover storage. In small spatial units greater importance is attributed to non-climatic physiographic conditions which modulate the effect of climatic factor on hydrologic processes. Some physiographic factors like geology, land relief are stable; others like land use, land cover or the growth phase of forest ecosystems vary in shorter time periods. Land management, both current and past, is an important factor modulating the present course of natural hydrologic processes. Land drainage, land cover changes or particular land management practices are the key factors in small spatial units.

Protection and management of more stable forms of wetlands like ponds, marshes, swamps and pools is of special ecologic and economic importance. Much has been recently done to stop degradation and to restore natural wet areas. Various factors may be responsible for declining water conditions of wetlands. Physiographic factors that alter water relations operate in combination and interact with each other. Those which vary in long-term scale are essential for the alteration of hydrologic conditions. The importance of particular factors is object-specific. Hence, the projects of restoration and protection of natural wetlands should consider both the effect of local physiographic features on water conditions and the possibility of wetlands restoration. Recommendation of particular projects and the selection of technical solutions are thus dependent on hydrologic survey. An assessment of the long term dynamics of climatic elements affecting hydrologic balance is of key importance in this context. An example of such assessment is presented in this paper.

\section{MATERIAL AND METHODS}

Hydrologic conditions were analysed in the catchment of the Dopływ spod Nowej Wsi of an area of $27.53 \mathrm{~km}^{2}$ and in smaller spatial unit - a natural seepage pond fed with groundwater called Bagna Ramuckie (c. 16.40 ha). Changes of water conditions were considered in a qualitative way - as the presence or absence of surface water over 150-year-long period. The catchment basin was not meteorologically controlled. Therefore, temperature and precipitation records for the years 1951-2000 were taken from meteorological station of the University of Warmia and Mazury in Tomaszkowo and temperature records for the years $1848-2005-$ from the IMGW station in Poznań-Ławica (Dane z stacji IMGW Poznań-Ławica... 2005, Dane ze stacji UWM Tomaszkowo... 2007). Station Tomaszkowo is situated $14 \mathrm{~km}$ from Bagna Ramuckie and $15 \mathrm{~km}$ from the centre of the catchment. Small spatial variability of meteorological elements (particularly of temperature) justifies such approach. 
Air temperatures from the IMGW station Poznań-Ławica were used to supplement data series from the station Tomaszkowo with temperatures from before (1848-1950) and after (2001-2005) the period recorded in the latter. The distance between Tomaszkowo and Poznań-Ławica is c. $280 \mathrm{~km}$. However, there was a strong linear relationship of mean monthly and annual temperatures between these localities (coefficients of determination $R^{2}=0.9755$ and 0.8215 for month and hydrologic years, respectively at respective N's $=600$ and 50). Moreover, the longest series of temperature measurements for distant cities like Krakow, Warsaw and Poznań show very similar directional variability in the study period (e.g. MiLER and MILER, 2000; BORYCZKA and STOPA-BORYCZKA, 2004). Hence, one might expect that the distance between the two localities and resulting differences in climatic conditions do not question the credibility of described procedure and that regression between measurements from the two meteorological stations is not accidental.

The procedure described above was not used in supplementing the data series of precipitation due to unsatisfactory, though statistically significant (respective $R^{2}=0.3182$ and 0.3458 at $\alpha<0.01$ ), relationship. Field evaporation was calculated with the Iwanow's method. Climatic water balance was set up for the years 1971-2000 . Cyclic course of temperatures and precipitations was assessed using Fourier's time series analysis. Changes of physiographic conditions affecting water conditions tions, changes of hydrographic network, and reclamations in the past were assessed with the use of archive and present maps, forest registers, land records, hydrographical records, historical sources and land reclamation documents.

\section{LOCATION AND PHYSIOGRAPHIC CHARACTERISTICS OF THE DOPŁYW SPOD NOWEJ WSI CATCHMENT BASIN}

The Dopływ spod Nowej Wsi catchment basin $\left(27.53 \mathrm{~km}^{2}\right)$ is situated in northern part of the forest complex Puszcza Napiwodzko-Ramucka in Warmia. The gauge section $\left(53^{\circ} 37^{\prime} 16^{\prime \prime} \mathrm{N}\right.$ and $\left.20^{\circ} 38^{\prime} 10^{\prime \prime} \mathrm{E}\right)$ is situated $15 \mathrm{~km}$ north of Olsztyn. According to physiographic regionalisation the catchment belongs to macroregion Pojezierze Mazurskie (842.8) and mesoregion Pojezierze Olsztyńskie (842.81) (KONDRACKI, 2002).

Climate of the area is transitional with some continental features like e.g. relatively high amplitude of temperatures $\left(\Delta t=21.2^{\circ} \mathrm{C}\right.$ for monthly averages) or a shift of maximum precipitation to early summer months. Mean annual air temperature is $7.2^{\circ} \mathrm{C}$. The coldest month is January (normal temperature $-3.3^{\circ} \mathrm{C}$ ), the warmest July (normal temperature $17.0^{\circ} \mathrm{C}$ ). Normal annual precipitation for the period 1951-2000 was $570 \mathrm{~mm}$. Snow cover lasts normally over 40 days a year and its thickness usually exceeds $50 \mathrm{~cm}$. Average precipitations in the vegetation period of the years 1951-2000 were $411 \mathrm{~mm}$. The area is characterised by a high number of 
cloudy days (more than 150 days a year on average) and high mean relative air humidity (c. 85\%). Vegetation period starts between $31^{\text {st }}$ March and $15^{\text {th }}$ April and ends between $31^{\text {st }}$ October and $5^{\text {th }}$ November. Thermal winter $\left(\mathrm{t}<0^{\circ} \mathrm{C}\right)$ usually starts around $5^{\text {th }}$ December and lasts c. 90 days. Thermal summer $\left(\mathrm{t}>15^{\circ} \mathrm{C}\right)$ starts around $10^{\text {th }}$ June and lasts usually 78 days. Annual climatic water balance is usually positive with water surplus of over $50 \mathrm{~mm}$. The period of deficit climatic water balance starts in March and ends in September.

According to the hydrographic division of Poland the Dopływ spod Nowej Wsi is a $6^{\text {th }}$ order stream and belongs to the drainage basin of the Pregola River. Glacial and fluvioglacial processes of the Baltic glaciations in Poznań and Pomeranian phases were the main factors that shaped geology, land relief and hydrographic network in the catchment. Hence, the catchment area is dominated by loose permeable formation of variable thickness exceeding $20 \mathrm{~m}$ on upland and underlined by moraine clays. The thickness of permeable grounds decreases in lower parts of the catchment where there are the outcrops of loamy strata.

Dominating land forms are outwash and bottom moraine hilly uplands. The catchment is a mixed cropland and forest area. The main forms of land use are forests $(59 \%)$ and grasslands (35\%). Dominating species in tree stands are: pine $(87 \%)$, oak (5\%), birch (4\%), spruce (3\%) and alder $(1 \%)$.

\section{TRANSFORMATION OF HYDROGRAPHIC NETWORK AND THE DYNAMICS OF NON-CLIMATIC PHYSIOGRAPHIC FEATURES}

Hydrographic network of contemporary the Dopływ spod Nowej Wsi catchment was not subjected to strong human impact till the first half of the $19^{\text {th }}$ century. There were Lake Kalno, smaller ponds and large marshes in an extensive depression between the present villages Nowa Wieś and Przykop (ACHREMCZYK, 1992; Mapa komornictwa olsztyńskiego..., XVII w.; Mapa..., 1809). Hydrographic conditions in the catchment at the beginning of the $19^{\text {th }}$ century and in the period of stabilised water table in Bagna Ramuckie are shown in Fig. 1.

According to BARCZEWSKI (1984) large-scale land drainage started in the first half of the $19^{\text {th }}$ century. A channel from Lake Lajs to Nowa Wieś was built. In those days Lake Kalno, neighbouring wetlands, lakes, ponds and pools were drained. Acc. to BARCZEWSKI (1984): "Large wetlands and peatlands among Nowa Wieś, Jaśniewo and Przykop, formerly flooded, are now being drained by the channel running to Lake Lajsk behind the Warmia border". Lake Kalno was shallow (max depth c. $4 \mathrm{~m}$ ), highly eutrophic and isolated water body surrounded by peatlands of variable water table dependent on meteorological conditions. According to BARCZEWSKI (1984): "Nowa Wieś was flooded in 1855 so that for two years people could get home only by boat. People suffered much misfortune in those days though fish could be caught just in front of their doors. Not earlier than in two years the channel to Lake Łajsk through Przykopskie Fields was completed." 


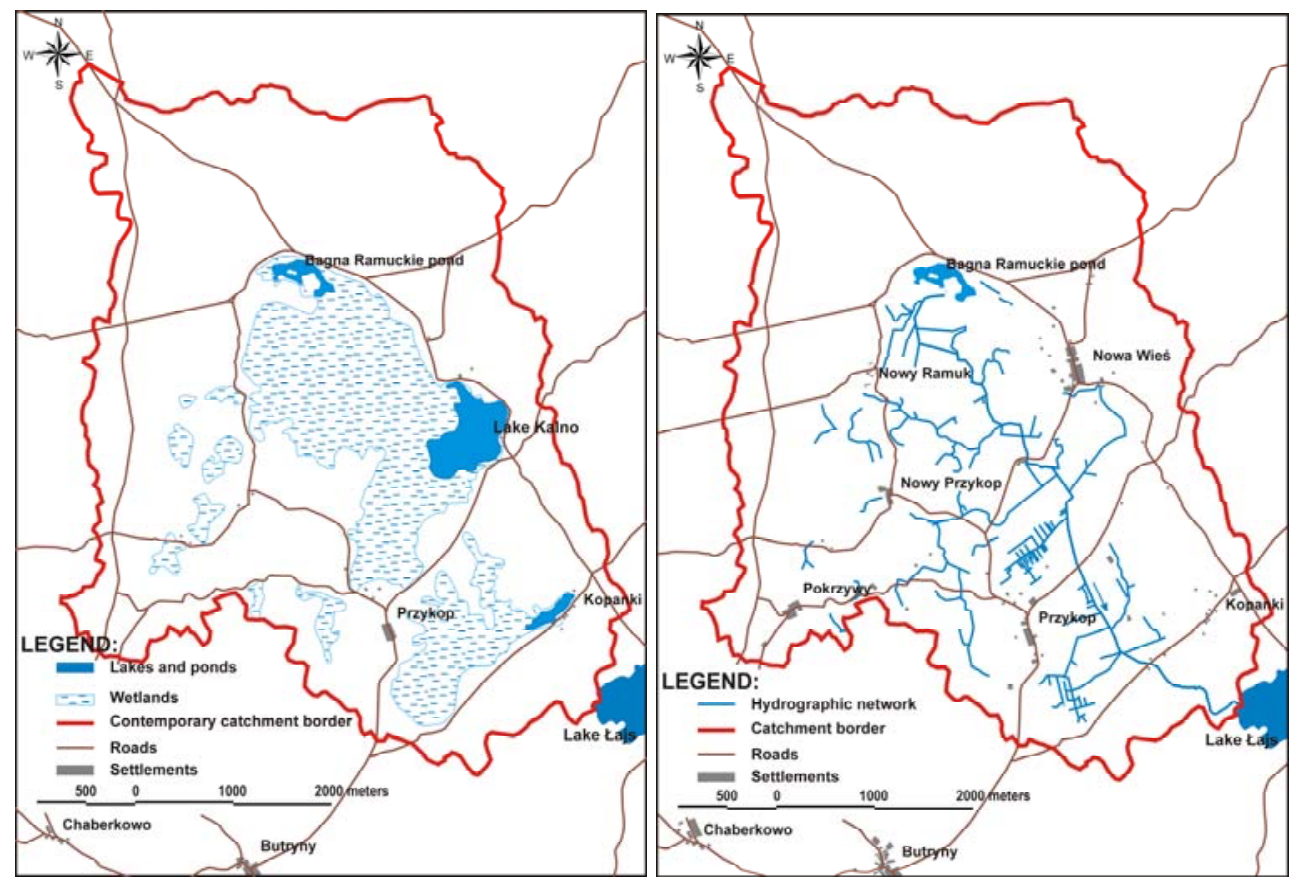

Fig. 1. Hydrographic network at the beginning of the $19^{\text {th }}$ century (left) and in the period of stable surface water table in Bagna Ramuckie pond (right)

Settlement in the catchment of the Dopływ spod Nowej Wsi markedly changed in the first half of the $19^{\text {th }}$ century. Villages like e.g. Nowa Wieś, Nowy Przykop and Pokrzywy were founded in those days. Forest clearing and drainage of wetlands were carried out. Construction of the channel Nowa Wieś - Lake Łajs was followed by detailed reclamation works which drained small local drainage blind depressions and pools and so reclaimed areas were intended for croplands. Hence, the agricultural enclave occupied formerly by the villages Butryny and Przykop markedly enlarged. Acc. to BARCZEWSKI (1984): “...the exchequer sold a chunk of forest by the road from Butryny to Olsztyn to found the village Pokrzywy in 1825. At separation in the year 1847 Butryny situated by the Masurian borderline obtained two thirds of fields and one third of forest which is now mostly clear cut. Biel, Laski, Borek, Właski, Wiejski turned out into fields...”.

Most reclamation works were done till 1914 and the rest with much less intensity - until 1945 (SOLARSKI et al., 2005). Such conclusions might be drawn by comparing German archive maps actualized for the years 1908, 1924 and 1938 with current maps and reclamation records (Mapa..., 1908; Mapa..., 1931; Mapa..., 1942; Mapa..., 1980; 1981a; 1981b; 1981c; 1982a; 1982b; Dokumentacja..., 2007). Objects of detailed reclamation from before the war were mainly open ditches. There were also some sections of underground pipelines. Most rec- 
lamation objects were well maintained after 1945 (Dokumentacja..., 2007). New drainage projects that would change the existing network of ditches in the Dopływ spod Nowej Wsi catchment were not finished after the year 1945.

Artificial catchment of the Dopływ spod Nowej Wsi was created as a result of draining large, primarily not drained areas with the system of open ditches. Surface outflow before reclamation works in the catchment was practically absent.

An analysis of archive maps revealed that the share of forests in the catchment basin of the Dopływ spod Nowej Wsi was relatively stable since the end of the $19^{\text {th }}$ century (BARCZEWSKI, 1984; Mapa..., 1899; Mapa..., 2007a; Mapa..., 2007b). The share of particular land use categories in the catchment was established at the end of the XX century when c. $4 \%$ of land cover (arable lands) were transformed into meadows and pastures for intensive cattle breeding (Studium..., 1999). Intensive forest management was established in the middle of the XIX century when oak and oak-pine tree stands were replaced by pine and spruce monocultures (now pine's contribution exceeds 83\%). Forest management by clear cutting was introduced in those days. (Mapa..., 1899; Plan..., 2005; Mapa..., 2007a; Mapa..., 2007b). Specific feature of present forests in the catchment is relatively large percent of old tree stands (mean age is 82 years). To sum up, non-climatic physiographic determinants of water conditions in the catchment did not vary much in the last several dozen years.

Surface water occurred in Bagna Ramuckie in the first half of the $19^{\text {th }}$ century. Its disappearance in the $19^{\text {th }}$ century was not documented. Cartographic documentation indicates, however, the lack of water and the presence of detailed reclamation objects in Bagna Ramuckie and in the surrounding at the end of the $19^{\text {th }}$ century. Noteworthy, reclamation network composed of open ditches was formed before World War II.

Bagna Ramuckie was used as meadows till the 1960s, the restoration of surface water table started afterwards. Water table enlarged markedly till the end of the 1970s. In the 1980s water table of the pool was stable to decline again at the end of the 1980s and beginning of the 1990s. Water disappearance intensified in the first half of the 1990s which ended up with a total lack of water table in Bagna Ramuckie in 1994. Now Bagna Ramuckie is a reed bed where surface water appears in a form of small pools in spring and usually disappears later on.

\section{THE DYNAMICS OF METEOROLOGICAL ELEMENTS}

Mean air temperatures increased since 1848 till the middle of the second decade of the $19^{\text {th }}$ century, decreased to the 1980s and increased again until 2005 (Fig. 2). Mean air temperature of the hydrologic year increased in the years 1848-1916. Trends of annual temperatures were formed by the variability of air temperatures in the winter half-year. Changes of temperatures in the hydrologic year and in the 


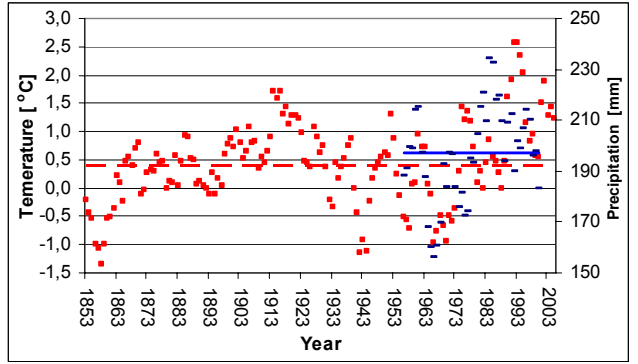

Winter half-year, 5 -year consecutive mean

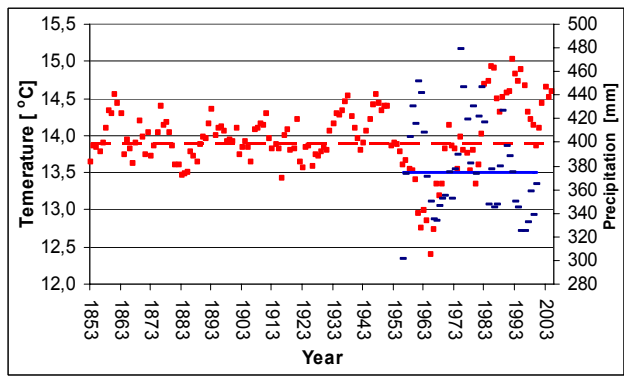

Summer half-year, 5-year consecutive mean

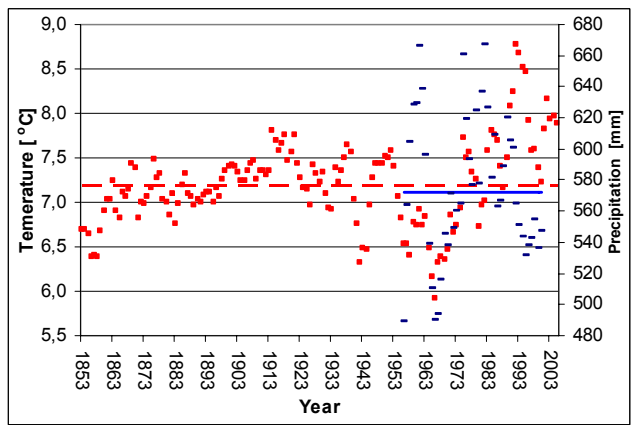

Hydrologic year, 5-year consecutive mean

$$
\text { - } \quad-\text { Temperature }
$$

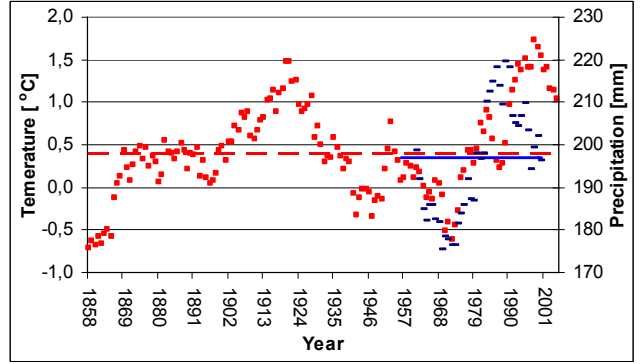

Winter half-year, 11 year consecutive mean

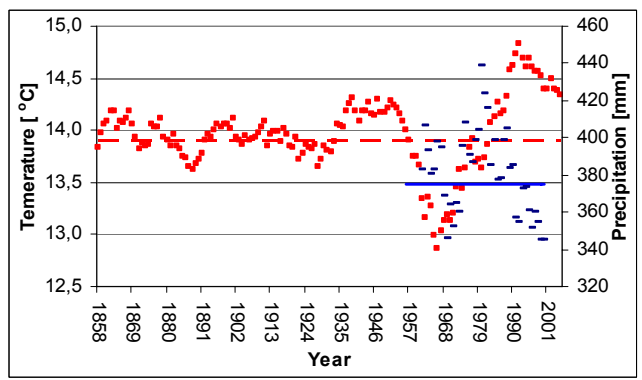

Summer half-year, 11-year consecutive mean

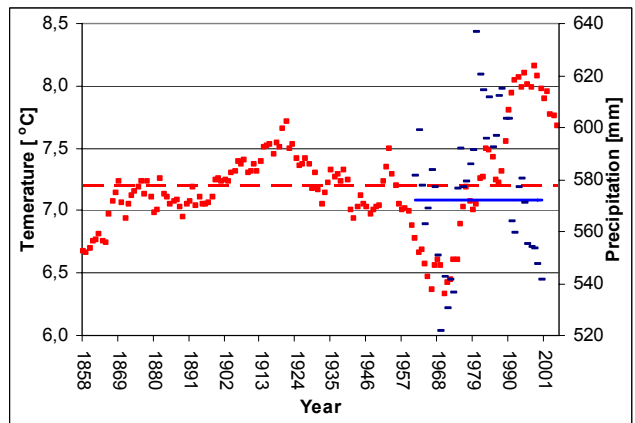

Hydrologic year, 11- year consecutive mean Precipitation

Fig. 2. Consecutive 5-year and 11-year mean temperature and precipitation against arithmetic mean values (horizontal line) for the hydrologic year, winter and summer half-years in 1848-2005 (temperature) and 1951-2000 (precipitation)

winter half-year were similar while the temperature of summer half-year did not show directional changes in this period (c. $0^{\circ} \mathrm{C} / 100$ years). Temperature increment in the period $1848-1916$ was $1.3^{\circ} \mathrm{C} / 100$ for the hydrologic year and $2.4^{\circ} \mathrm{C} / 100$ years for the winter half-year. Temperature tended to decrease in the later period ending in the 1970s. Mean temperature of hydrologic year, winter half-year and summer half-year decreased by $1.7,1.3$ and $1.5^{\circ} \mathrm{C} / 100$ years, respectively, in the period 1917-1973. Later on the mean temperatures increased again by 2.1, 1.9 and 

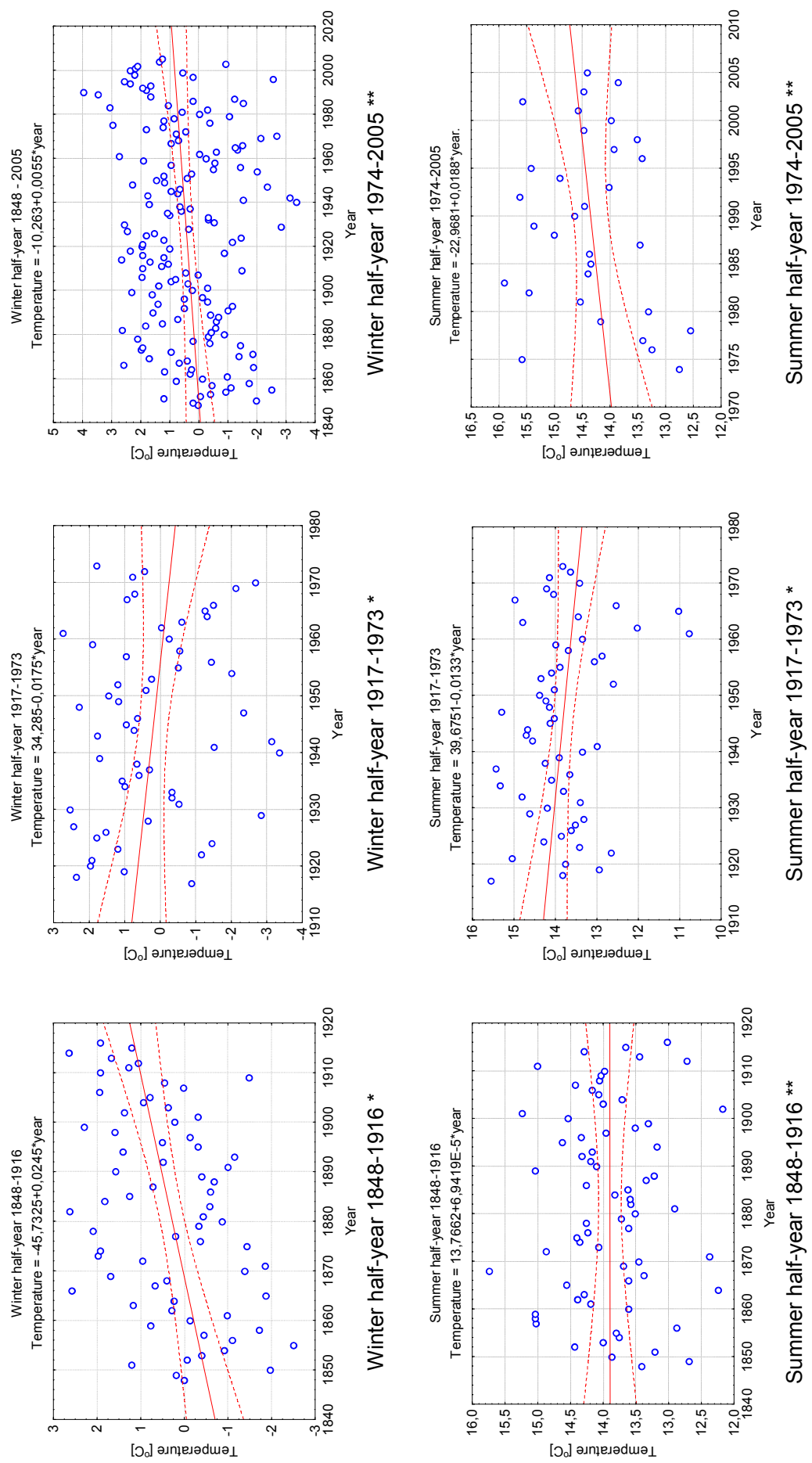

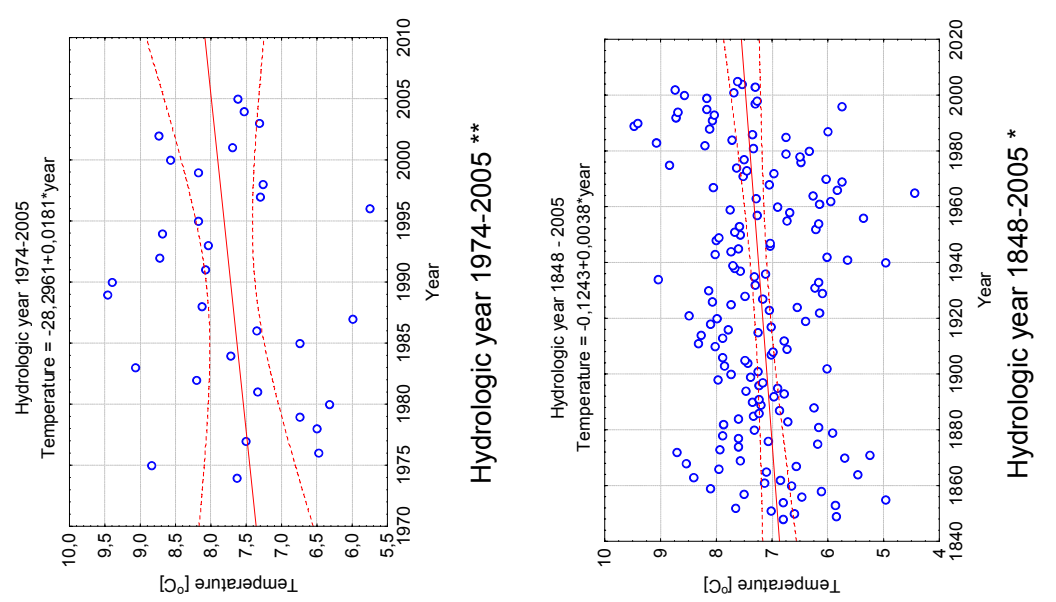

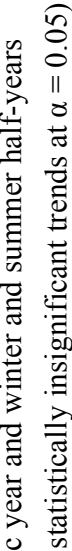

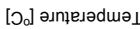
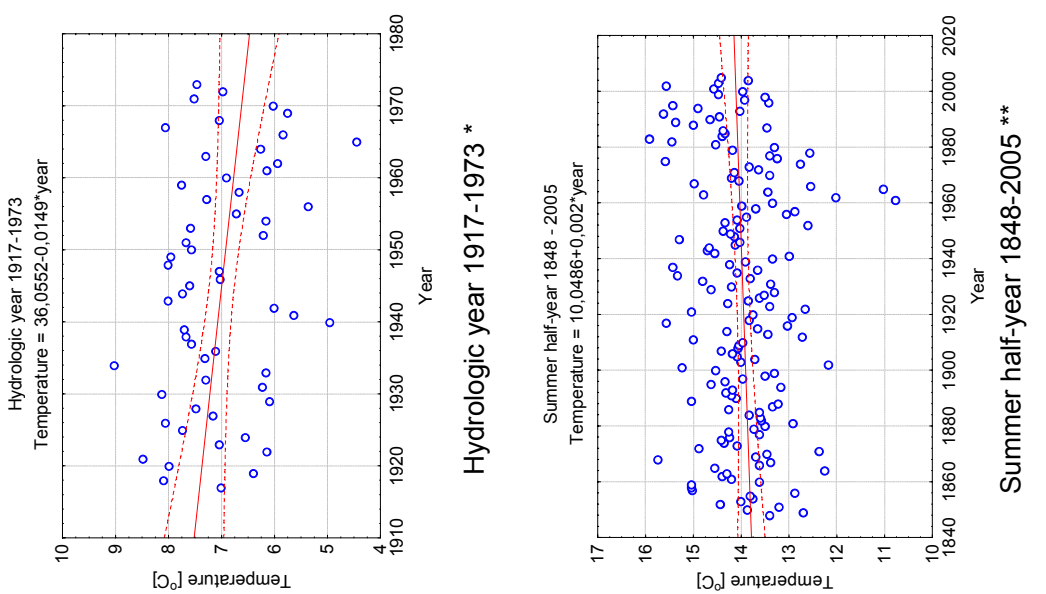

¿

$\stackrel{Ð}{\leftrightarrows}$

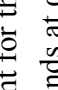

(

冚

范当

$3 \cdot \frac{\pi}{n}$

乙.

㐘
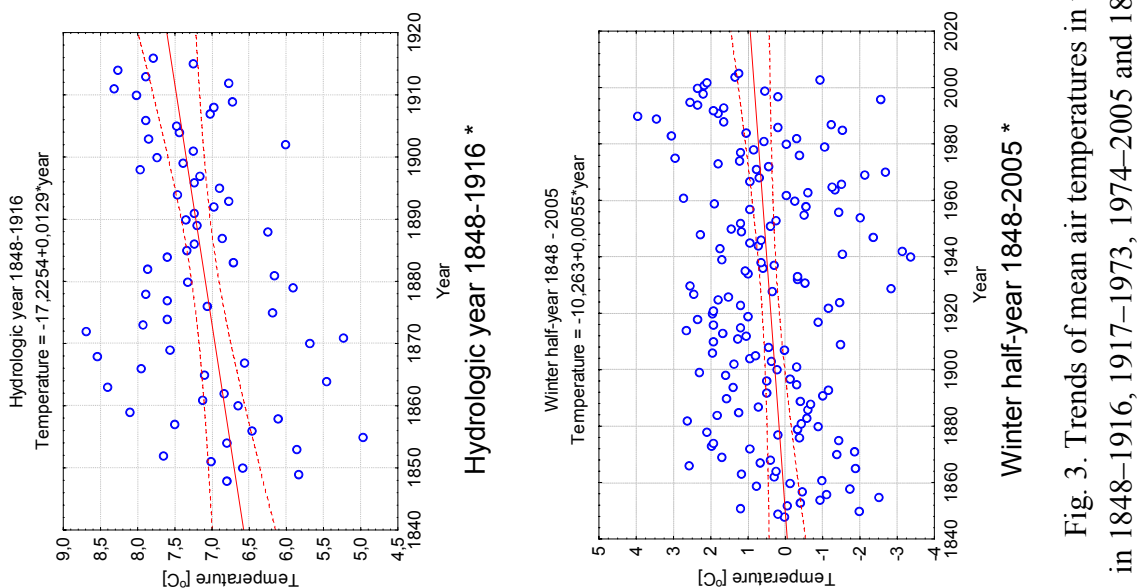
$1.8^{\circ} \mathrm{C} / 100$ years for the hydrologic year, winter half-year and summer half-year, respectively, in the period 1974-2005. In the whole analysed period between 1848 and 2005 temperatures of the hydrologic year, winter half-year and summer halfyear increased by $0.6,0.2$, and $0.4^{\circ} \mathrm{C} / 100$ years, respectively. Temperatures of the winter period showed similar long term variability as those of the hydrologic year. Moreover, the dynamics of temperatures of the winter half-years was more distinctive and explicit than that of the summer half-years (Fig. 3).

The coldest period lasted from 1951 till 1980. Thermal minimum for the years 1848-2005 occurred in the years 1961-1965 and thermal maximum - in the years 1990-1995. The years 1985-2005 were warmest of the whole period from 1848 till 2005.

In contrast with temperatures, there were no directional changes in precipitation. Periodicity of temperatures and precipitation is illustrated in Figure 4. Dominating cycles for temperature were 5,40 and 78 years while for precipitation one may distinguish cycles of 2,5 and 8 years.
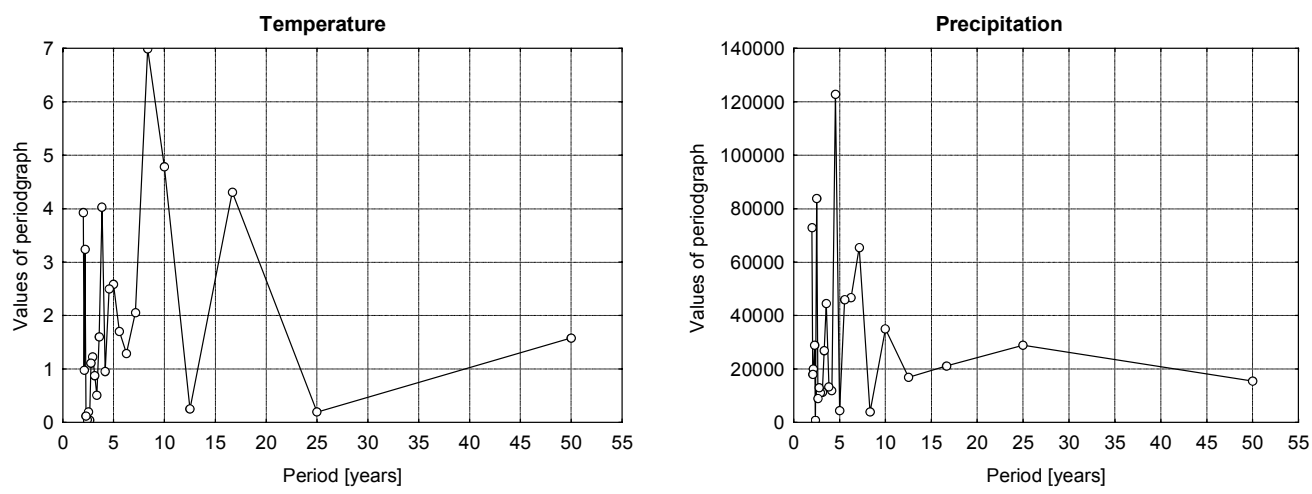

Fig. 4. Periodgraph of mean annual air temperature and annual precipitation in the years 1848-2005 for temperature (left) and in 1951-2000 for precipitation (right)

Sums of annual precipitation varied in the years 1951-2000. The years 1951-1955 and 1960-1965 were dry while the years 1955-1961 and 1976-1980 were wet. Winter precipitations were more uniform than the summer ones - dry periods occurred in the years 1961-1965 and 1970-1975 and wet periods - in the years 1981-1985. Dry periods in summer half-years occurred in 1951-1955, 1961-1965 and 1991-1995 and wet periods - in the years 1956-1960 and 1971-1980. Usually, precipitations increased in the periods of higher temperatures but in the 1960s at low mean temperatures the sums of precipitation exceeded long-term average values. However, at the end of the 1980s and the beginning of the 1990s the sums of precipitation decreased and mean temperatures increased (Figs 2 and 3 ). 
In the period 1970-2000 mean values of the climatic water balance for winter half-years and hydrologic years were positive $-88 \mathrm{~mm}$ and $75 \mathrm{~mm}$, respectively. The end of the 1980s and the beginning of the 1990s was characterised by marked deficit of climatic water balance - total sum of the balance was $-60 \mathrm{~mm}$ in the years 1989-1993. The largest surplus of climatic water balance was found in the years 1977-1981 - its combined sum was $1152 \mathrm{~mm}$. In general, the 1970s and the first half of the 1980s was the period of climatic water balance surplus (Fig. 5).

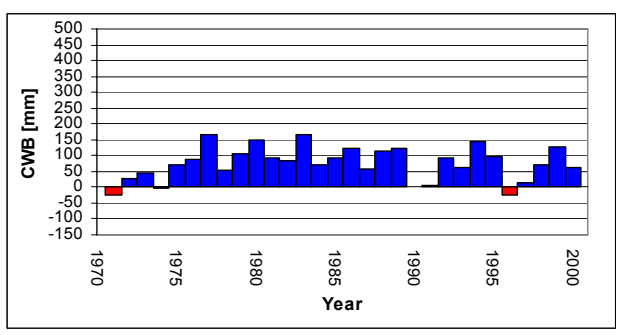

Winter half-year

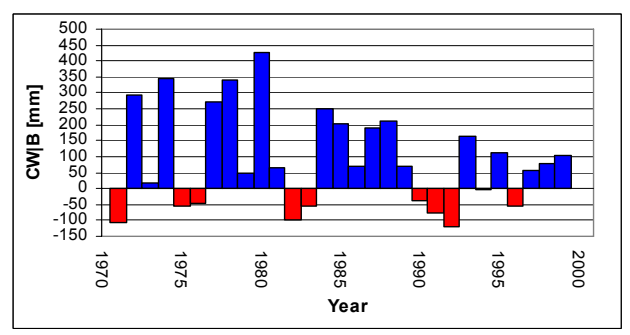

Hydrologic year

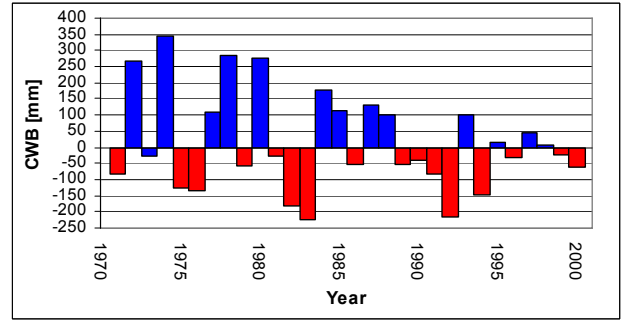

Summer half-year

Fig. 5. Climatic water balance in the Dopływ spod Nowej Wsi catchment for the hydrologic year, winter and summer half-year periods in $1971-2005$

\section{SUMMARY AND CONCLUSIONS}

The cause for periodical changes in hydrologic conditions which expressed themselves as the appearance and disappearance of surface waters in the Doplyw spod Nowej Wsi catchment might be seen in the dynamics of meteorological conditions affecting water balance. Particularly important in longer periods were temperature changes which increased (in 1848-1916 and 1974-2005) or decreased (1917-1973) evapotranspiration. Temperature dynamics stimulated or destimulated water input or output and restoration or reduction of water table in Bagna Ramuckie pond area. Trends of temperature changes were more distinct in the winter period when catchments are usually researched.

Changes in atmospheric precipitation were of secondary importance for the fluctuation of water table over the longer time periods. No long-term trends of precipitation were noted in the study area between 1950 and 2001. Noteworthy, much shorter data series were available for precipitation than for temperatures. However, 
the analysis of data series for other areas in Poland confirms a lack of long-term directional changes in precipitation and only cyclic changes in periods reaching back to the beginning of the $19^{\text {th }}$ century (e.g. MILER and MILER, 2000; BORYCZKA and STOPA-BORYCZKA, 2004). Precipitation cycles were important for recharge in the shorter periods of several years. Cyclically high sums of precipitation stimulated the restoration and stabilisation (in the years 1958-1963, 1972-1974, 1978-1980) or reduction (1989-1993) of the water table in the pond. Episodes of large and long-lasting snow retention were of some importance since they made an additional hydrologic effect (like that in 1980).

Restoration of the water table in Bagna Ramuckie pond started in the middle of the 1960s. Water table disappeared there in the first half of the 1990s. In the year 1981 surface area of the pond was 12.5 ha at a maximum depth of $2.5 \mathrm{~m}$. Historic documents indicate that surface water in Bagna Ramuckie and in its surroundings was present in the past and disappeared in the second half of the $19^{\text {th }}$ century. The presence of many pools, ponds and wetlands in the catchment basin of the Dopływ spod Nowej Wsi until the middle of the $19^{\text {th }}$ century was an effect of cold climate which persisted in Europe since late Medieval ages (TREPIŃSKA, 2001). One may think that trends of temperature and large-scale drainage in the $19^{\text {th }}$ century caused the disappearance of surface water in Bagna Ramuckie pond in the second half of the $19^{\text {th }}$ century. It is hard to judge which of these factors was decisive for disappearance of wetlands from the Dopływ spod Nowej Wsi catchment. However, the next episode of surface water persistence between the 1960s and 1990s occurred at a small variability of non-climatic physiographic features in the catchment. Moreover, restoration of surface waters in wetlands was also observed in many neighbouring catchments. Hence, the importance of climatic factor in the $20^{\text {th }}$ century should be considered dominating.

One may think that restoration of water retention in Bagna Ramuckie was mainly the effect of a long period of temperature decline. In the period preceding the restoration of water retention temperature declined for c. 40 years. Moreover, spectacular effect of water appearance in the catchment may be associated with thermal minima that occurred in the 1960s combined with high precipitations characteristic for the late 1950s. Water table disappeared due to 20-years-long rise of temperature coinciding with dry period in the beginning of the 1990s. Relative stability of water table during its existence in the pond might be explained by favourable dynamics of climatic water balance - the rise of temperature and evapotranspiration was usually accompanied by the increase in precipitation. Hence, water table remained stable for c. 20 years. Disturbance of water balance in the beginning of the 1990s caused disappearance of surface waters in Bagna Ramuckie.

Geologic and geomorphologic conditions prevailing in the catchment favour water retention in the saturation zone which may explain the duration of surface water restoration in Bagna Ramuckie. Remarkable thickness of surface permeable formations of high porosity (24-35\% for typical grounds like sand and gravel), 
small hydraulic gradient of aquifer floor (1.3\% on average), concave floor, small terrain inclinations, no convergence of slopes to streams, and large percent of nondrained areas determine large water storage capacity of the first aquifer and a great inertia of hydrologic system of the Dopływ spod Nowej Wsi catchment basin.

\section{REFERENCES}

1. ACHREMczyK S., 1992, Historia Warmii i Mazur: od pradziejów do 1945 roku. Bibl. Olszt., 18. Olsztyn, OBN.

2. BARCZEWSKI W., 1984. Kiermasy na Warmii i inne pisma wybrane. Olsztyn, Wydaw. Pojezierze: 220.

3. BoryczKa J., StOpa-BoryczKa M., 2004, Cykliczne wahania temperatury i opadów w Polsce w XIX-XXI w. Acta Agrophys., 3(1): 21-33.

4. Dane ze stacji IMGW Poznań-Ławica za lata 1848-2005, 2005. Poznań, IMGW maszyn.

5. Dane ze stacji UWM Tomaszkowo za lata 1848-2005, 2007. Olsztyn, UWM, KMiK maszyn.

6. Dokumentacja ewidencyjna obiektów melioracyjnych dla obrębów Butryny, Przykop, Nowa Wieś, 2007. Olsztyn, ZSW maszyn.

7. KONDRACKI J., 2002. Geografia regionalna Polski. Warszawa, PWN: 450.

8. Mapa drzewostanowa nadleśnictwa Nowe Ramuki w skali 1:20 000, 2007a. Nowe Ramuki, Nadleśnictwo.

9. Mapa drzewostanowa nadleśnictwa Nowe Ramuki w skali 1:25 000, 1899. Nowe Ramuki, Nadleśnictwo.

10. Mapa drzewostanowa nadleśnictwa Olsztyn w skali 1:20 000, 2007b, Olsztyn, Nadleśnictwo.

11. Mapa Karte für die Manöver der 1. u. 2. Division u. des 1. Armeekorps w 1:100 000. 1908.

12. Mapa Karte von Ost - Preussen nebst Preussisch Lithauen und West Preussen w skali 1:150 000 , Wartemburg (s17+23), 1809. Berlin.

13. Mapa komornictwa olsztyńskiego. XVII w. Delineatio geographica cameratus Allensteinensis. Olsztyn, Arch. Diec. Warm.

14. Mapa Messtischblatt Karte 2389 Wuttrinen (Butryny) w skali 1:25000. (Akt. 1938), 1942. Berlin, $\mathrm{OKH}$.

15. Mapa Passenheim w skali 1:100 000 (Akt. 1924), 1931. Warszawa WIG..

16. Mapa topograficzna w skali 1:10 000. Arkusz 232.222 Przykop (Akt. Top. 1980, kart. 1981), 1981a. Warszawa, GEOKART.

17. Mapa topograficzna w skali 1:10 000. Arkusz 232.224 Nowa Kaletka (Akt. Top. 1980, kart. 1981), 1981b. Warszawa, GEKART.

18. Mapa topograficzna w skali 1:10 000. Arkusz 233.111 Nowa Wieś (Akt. Top. 1980, kart. 1981), 1981c. Warszawa, GEOKART.

19. Mapa topograficzne w skali 1:10 000. Arkusz 222.444 Ruś (Akt. Top. 1980, kart. 1982), 1982a. Warszawa, PPGK.

20. Mapa topograficzne w skali 1:10 000. Arkusz 223.333 Purda (Akt. Top. 1980, kart. 1982), 1982 b. Warszawa, PPGK.

21. Mapa w skali 1:10 000. Arkusz 233.113 Małaszewo (Akt. Top. 1976, kart. 1980), 1980. Warszawa: GEOKART.

22. Miler A.T., Miler M., 2000. Trendy i okresowości zmian temperatury oraz opadów dla Poznania w latach 1848-2000. Zesz. Nauk. PKoszal. Wydz. Bud. Inż. Środ., Inż. Środ., 22: 945-956.

23. Plan urządzania lasu Nadleśnictwa Nowe Ramuki na lata 2005-2014, 2005. Nowe Ramuki, Nadleśnictwo maszyn.

24. SolArSki H., BłaszCZYK M., SolARSKi K., 2005. Drenowanie gruntów ornych na obszarach morenowych pojezierza Mazurskiego. Rocz. AR Pozn. Ser. Melior. Inż. Środ., 365: 401-407. 
25. Studium uwarunkowań i kierunków zagospodarowania przestrzennego Gminy Purda, 1999. maszyn.

26. TREPIŃSKA B., 2001. Fluktuacje termiczne w Europie od małej epoki lodowej do końca XX wieku. Postęp badań zmian klimatu i ich znaczenie dla życia i gospodarczej działalności człowieka. Warszawa, WGSR UW.

\section{STRESZCZENIE}

\section{Przebieg warunków klimatycznych oraz wpływ melioracji wodnych na stosunki wodne pojeziernych obszarów bezodpływowych}

Słowa kluczowe: melioracje wodne, obszary wodno-błotne, przebieg elementów klimatu, rozlewisko, zanik wody powierzchniowej

W pracy podjęto próbę oceny wpływu elementów klimatu oraz sieci melioracyjnej na stosunki wodne pojeziernych obszarów bezodpływowych. Wybrano obiekt badawczy, w przypadku którego wieloletnią zmienność nieklimatycznych czynników fizyczno-geograficznych na warunki wodne można pominąć. Badane jednostki przestrzenne to zlewnia Dopływu spod Nowej Wsi $\left(27,53 \mathrm{~km}^{2}\right)$ oraz jedno z rozlewisk położone w tej zlewni o nazwie Bagna Ramuckie (obszar Warmii). Rozpatrywano okres od pierwszej połowy XIX w. do 2005 r.

Najistotniejszymi czynnikami kształtującymi procesy odbudowy i zaniku wody powierzchniowej były trendy termiczne w dłuższych okresach. Ponowne wystapienie wody powierzchniowej na rozlewisku w XX w. nastapiło po ok. 40-letnim okresie spadku temperatury, natomiast zanik - po okresie 20-letniego wzrostu temperatury w połowie lat 90 . XX w. Opady w okresach dłuższych nie wykazywały kierunkowych zmian i ze względu na zmienność cykliczną miały dodatkowe znaczenie modulujące w okresach krótkich - stymulujące lub destymulujące proces odbudowy powierzchni lustra wody. Pierwszy epizod redukcji powierzchni lustra wody i jego zaniku na Bagnach Ramuckich można wiązać zarówno z kierunkowymi zmianami temperatury, jak i prowadzonymi wówczas pracami odwodnieniowymi oraz zmianą sposobu gospodarowania w zlewni. W XX w. nieklimatyczne czynniki fizyczno-geograficzne oraz sposób prowadzenia gospodarki wodnomelioracyjnej miały raczej charakter mało zmienny. Dlatego można sądzić, że w tym okresie znaczący wpływ na procesy odbudowy i zaniku powierzchni lustra wody w rozlewisku miała głównie zmienność klimatu.

Reviewers:

Prof. Waldemar Mioduszewski

Dr. Jan Tyszka 